Khatun, N., \& Tamanna, M. (2020). Factors Affecting the Adoption of Fintech: A Study Based on the Financial Institutions in Bangladesh. Copernican Journal of Finance \& Accounting, 9(4), 51-75. http://dx.doi.org/10.12775/CJFA.2020.021

\author{
Nasima Khatun* \\ East West University \\ Marzia Tamanna** \\ East West University
}

\title{
FACTORS AFFECTING THE ADOPTION OF FINTECH: A STUDY BASED ON THE FINANCIAL INSTITUTIONS IN BANGLADESH
}

Keywords: fintech, UTAUT, SEM, FIs, Bangladesh.

J E L Classification: G2, G4.

Abstract: Financial technology (Fintech) refers to software and other modern techno-
logies to provide automated and improved financial services. We surveyed to examine
the factors influencing the adoption of Fintech in the financial institutions of Bangla-
desh with the help of the Unified Theory of Acceptance and Use of Technology (UTAUT)
model and selected eight influencing factors. Before collecting data, a well-structured
face-to-face survey was arranged. Structural Equation Modeling (SEM) with Genera-
lized Least Squares method has been used to analyze the primary data gathered from
265 employees. The results verified that effort expectancy, social influence, facilitating
condition, perceived reliability, added value positively influence the behavior intention

Date of submission: December 21, 2020; date of acceptance: March 3, 2021.

* Contact information: nasima@ewubd.edu, Department of Business Administration, East West University, Dhaka, Bangladesh, phone: +880-2-09666775577 Ext: 184; ORCID ID: https://orcid.org/0000-0002-8418-6783.

** Contact information: marziamis@ewubd.edu, Department of Business Administration, East West University, Dhaka, Bangladesh, phone: +880-2-09666775577 Ext: 290; ORCID ID: https://orcid.org/0000-0001-5989-0640. 
to adopt Fintech. Additionally, the age of the respondents has a significant moderating effect on almost all the factors on Fintech adoption.

\section{IIINTRODUCTION}

In emergent countries like Bangladesh, Fintech is poised to speed up financial inclusion. Other such countries like India have already embraced many components of Fintech and its earning profits (Sadrul Huda, Kabir, Popy \& Saha, 2020). Today, more than 35 million people in Bangladesh do not have a bank account, and their economic activities are not part of the country's formal economy. The goal of Fintech is to improve the customer's services and financial services more efficiently (Chen, 2016).

According to (Zavolokina, Dolata \& Schwabe, 2016), though many generous amounts of research address the banking sector and financial services, few scholars have touched on the Fintech industry. In the financial sector, Fintech has a massive impact. Because of the changes in an increase in service usage and differences in perception, the positive impact of Fintech is increasing the volume of the whole financial market (Lee \& Kim, 2015).

Fintech services are being introduced in Bangladesh to improve \& develop financial services for the people; many researchers have spoken about the related issues of this type of technology (Hossain, 2020).

We have pinpointed the variables that influence the usage of Fintech in financial sectors. It is expected that proper adoption of Fintech would increase the ability of decision-makers to apply innovative and efficient strategies for improving the usage of Fintech by manipulating and controlling the independent variables. Besides, the existing literature on technology adoption discloses the significance of understanding the behavioral intention factors.

\section{LITERATURE REVIEW}

In the past couple of years, study on Fintech has been rising dramatically due to acknowledging the Fintech ethics in financial institutions. The researchers have given considerable attention to Fintech because of the exponential increase in technologies and mobile phone usages. The upsurge of investments in Fintech from USD 4.05 billion in 2013 to USD 22.2 billion in 2015 offers boundless possibilities for further research and inventive concepts (Skan, 2015). 
According to (Puschmann, 2017) , financing, cross-process, investment, and payment are the most significant factors of the emerging Fintech market. Guild (2017) demonstrated that to break new ground on finance and enlarge financial services to hundreds of millions of people lacking access to Fintech innovations include peer-to-peer lending platforms and digital cash transfer services (BTRC, 2020).

Hornuf (2018) found that until 2015 followed by Canada, China, India, and the UK, the USA had the largest Fintech market. He subcategories the Fintech in insurance, exchanges, payment, regulatory technology, assets management, loyalty programs, and other business activities.

Chakraborti (2019) revealed that the use of Fintech technology emergently increasing day by day as the country's mobile subscription density is very high.

Table 1. Summary of the research on uses of Fintech in different developed and developing countries

\begin{tabular}{|c|c|c|c|c|}
\hline Author & Country & Theoretical framework & Objectives & Key factors of Fintech \\
\hline $\begin{array}{l}\text { James Guild } \\
\text { (2017) }\end{array}$ & $\begin{array}{l}\text { Kenya, } \\
\text { India \& China }\end{array}$ & $\begin{array}{l}\text { Qualitative assessment } \\
\text { (using contemporary } \\
\text { media accounts, } \\
\text { Academic analysis \& } \\
\text { Central bank statistics) }\end{array}$ & $\begin{array}{l}\text { To endorse financial } \\
\text { inclusion in each case } \\
\text { of how the monitoring } \\
\text { architecture impacted } \\
\text { the adoption of Fintech. } \\
\text { When the objective } \\
\text { is to expand access to } \\
\text { financial resources, } \\
\text { explaining this variance } \\
\text { will offer insight into the } \\
\text { most suitable regulatory } \\
\text { method. }\end{array}$ & $\begin{array}{l}\text { Digital cash transfer } \\
\text { services, peer-to-peer } \\
\text { lending platforms, } \\
\text { complementary } \\
\text { government policies, } \\
\text { and regulatory } \\
\text { frameworks }\end{array}$ \\
\hline $\begin{array}{l}\text { Tae-heon Lee } \\
\text { and } \\
\text { Hee-Woong } \\
\text { Kim (2015) }\end{array}$ & Korea & $\begin{array}{l}\text { Qualitative Study, System } \\
\text { Dynamics with Causal } \\
\text { Loop Diagram (CLD) }\end{array}$ & $\begin{array}{l}\text { To stimulate the } \\
\text { crowdfunding industry } \\
\text { by growing Fintech } \\
\text { companies and hopes } \\
\text { for financial stimulation } \\
\text { as well. }\end{array}$ & $\begin{array}{l}\text { Crowdfunding, Fintech, } \\
\text { System Dynamics }\end{array}$ \\
\hline $\begin{array}{l}\text { Ion Micu } \\
\text { and Alexandra } \\
\text { Micu (2016) }\end{array}$ & Romania & Case Study & $\begin{array}{l}\text { To investigate the } \\
\text { execution of Fintech } \\
\text { on the Bucharest } \\
\text { Stock Exchange (BVB), } \\
\text { explained by the financial } \\
\text { service providers and } \\
\text { solutions intended to } \\
\text { provide better services } \\
\text { in the form of online } \\
\text { trading platforms. }\end{array}$ & $\begin{array}{l}\text { Financial technology; } \\
\text { Fintech; Romanian stock } \\
\text { market; BVB; Capital } \\
\text { markets }\end{array}$ \\
\hline
\end{tabular}


Table 1. Summary...

\begin{tabular}{|l|l|l|l|l|}
\hline \hline \multicolumn{1}{|c|}{ Author } & Country & Theoretical framework & \multicolumn{1}{c|}{ Objectives } & Key factors of Fintech \\
\hline \hline $\begin{array}{l}\text { Hua Wilfried } \\
\text { Serge Koffi } \\
\text { (2016) }\end{array}$ & West African & Qualitative analysis & $\begin{array}{l}\text { To identify the present } \\
\text { west African financial } \\
\text { sector, it evaluates } \\
\text { the financial market } \\
\text { segments and digitization } \\
\text { reimbursement. To } \\
\text { detail, the customer } \\
\text { population financial } \\
\text { sector forms an } \\
\text { immense amount of data } \\
\text { exploiting by Fintech } \\
\text { companies. }\end{array}$ & $\begin{array}{l}\text { Financial Services, } \\
\text { Fintech Revolution, } \\
\text { Banking, West Africa } \\
\text { Economy Monetary } \\
\text { and Analytics, Artificial } \\
\text { Intelligence, Payments, } \\
\text { Digital currencies, Crowd } \\
\text { Funding }\end{array}$ \\
\hline $\begin{array}{l}\text { Jarunee } \\
\text { Wonglimpiyarat } \\
\text { (2017) }\end{array}$ & Thailand & Case study & $\begin{array}{l}\text { To identify the direction } \\
\text { of Fintech-based } \\
\text { innovation and insightful } \\
\text { implications on the } \\
\text { banking industry's } \\
\text { systemic nature. }\end{array}$ & $\begin{array}{l}\text { Prompt Pay Fintech - } \\
\text { the e-payment system in } \\
\text { Thailand, Fintech-based } \\
\text { systematic innovation } \\
\text { progress in the banking } \\
\text { industry. }\end{array}$ \\
\hline $\begin{array}{l}\text { Vieqi Rakhma } \\
\text { Wulan (2017) }\end{array}$ & Indonesia & $\begin{array}{l}\text { Descriptive qualitative } \\
\text { research }\end{array}$ & $\begin{array}{l}\text { To identify the practice } \\
\text { of Fintech in Indonesia }\end{array}$ & $\begin{array}{l}\text { Penetrated Fintech } \\
\text { technology like credit } \\
\text { card, Bank main frame } \\
\text { computer, ATMs. }\end{array}$ \\
\hline \hline
\end{tabular}

S o u r c e : summary of the research table created by authors.

\section{THEORETICAL FRAMEWORK}

Different theoretical models have been constructed to analyze the adoption behavior of new technologies in the market in previous times. Fintech research has long been studied how and why individuals or institutions use new technologies (Skan, 2015). Almost all the models were being used with a variety of independent variables, but they were found to be inappropriate in information technology (Venkatesh, Thong \& Xu, 2012). Compared to all other models like Technology Acceptance Model (TAM), UTAUT, Theory of Reasoned Action (TRA), we preferred UTAUT model initially used by Venkatesh in 2003. This model aims to achieve a unified view of user acceptance whenever a new technology enters in market. Many other researchers, including Hong, Thong, Chasalow, Dhillon have used this model to examine the behavior intention and technology adoption of the users.

We have applied both UTAUT (Venkatesh, Morris, Davis \& Davis, 2003) and UTAUT 2 (Venkatesh et al., 2012). From basic UTAUT, we evaluated and finally 
selected the factors fitted for developing countries, including Bangladesh. As UTAUT 2 is a more explanatory model with the proper suggestion for future work, we also followed this to broaden our idea within the base model's theoretical horizon. However, considering the nature of users and culture of the country, we have modified the whole model and included some additional factors as extensions to the UTAUT but within the same concept.

After setting our model, we wanted to see the relationship between independent variables- performance expectancy, effort expectancy, social influence, facilitating conditions, perceived reliability, price added value, nervousness, and dependent variable as behavioral intention to use technology. We expected that if the hypotheses we postulated for each of the variables are accepted, the users' behavioral intention will finally be converted to the actual usage of Fintech. Additionally, if we look at UTAUT models used primarily by Venkatesh, we can observe that he added moderating factors to verify its impact with independent variables. Since technology adoption in developing countries mostly depends on generation, we set age of the employees as the moderator, which is expected to contribute to evaluating the intensity between the independent variables and dependent variables. Even though some previous studies (Vasiljeva, 2016) claimed that gender plays a crucial role in the community but analyzing the financial sectors, with the help of our feasibility study, we concluded that all other things remaining the same, gender cannot be a moderating factor for Fintech adoption, especially in financial sectors.

\section{VARIABLES WITH HYPOTHESIS ANALYSIS}

\section{Performance Expectancy (PE)}

Our first independent variable used as the confirmatory factor in UTAUT is performance expectancy, which can be defined as the degree to which a technology user believes that if an individual adopts Fintech, it will help him/her attain job performance. Users are expected to be motivated to adopt new technology if they realize that this technology is more advantageous in their every working day. Previous studies (Brandl \& Hornuf, 2017) proved that PE can be a vital factor for the users' behavior intention to use new technology. Empirical studies also demonstrated that the more users would adopt the higher the PE, the more likely new technology like Fintech. 
H1: Performance expectancy influences the behavioral intention to adopt Fintech.

\section{Effort Expectancy (EE)}

Effort Expectancy is defined as the degree of ease associated with using the system (Venkatesh et al., 2003). If using technology is clear and understandable for users, they feel convenient and simple for them and want to be connected to that technology. Previous studies (Yongwoon Shim, 2016) identified that EE is an important factor affecting the users' behavioral intention to use technology.

H2: Effort expectancy has a positive influence on the behavioral intention of the users to adopt Fintech.

\section{Social Influence (SI)}

In accordance with (Venkatesh et al., 2003) social influence is defined as the degree to which an individual perceives that significant others believe they should use a new system. Generally, people surrounding the environment can play a vital role in changing behavior. Similarly, institutions in the same industry may act as role players in contributing to Fintech adoption. We picked social influence as one of the vital factors to analyze whether Fintech adoption of the related organizations influences behavior intention to Fintech users.

H3: Social influence positively influences the behavioral intention to adopt Fintech

\section{Facilitating Condition (FC)}

Facilitating condition is defined as the degree to which an individual believes that an organization and technical infrastructure exist to support system use (Venkatesh et al., 2003). As we know, financial institutions get Fintech support from Information Technology (IT) based firms; with the help of this factor, we tried to focus on whether the employees or users of Fintech get all the supports from the facilitator firms even when they face difficulty in using technology. Previous studies (Steele, Secombe \& Wong, 2009) found that FC can act as 
a core component of perceived behavior, especially when the facilitating firms provide a significant level of support to the user firms.

H4: Facilitating condition positively influences the behavioral intention to adopt Fintech

\section{Perceived Reliability (PR)}

Perceived reliability can be defined as the degree to which a user believes that with the help of new technology, she will perform a job consistently and accurately (Lee, Lee \& Eastwood, 2003). It is the perception of confidence and trust of the users while interacting with new technology. The service providers promise this trustworthiness. To cross-check the variable impact on the Fintech users, we questioned whether they acquire exact and error-free Fintech services from the IT firms, whether the service is consistent over time. If the users get support and feel the system is user-friendly, they will perceive Fintech as reliable and trustworthy. So, this factor can be a crucial determinant influencing the behavioral intention to use and consequently to the actual usage of this technology.

H5: Perceived reliability positively influences the behavioral intention to adopt Fintech

\section{Added Value (AV)}

The users' cognitive trade-off between the perceived benefits of the applications and the monetary cost for using them is defined as the price added value (Venkatesh et al., 2012). Generally, users tend to compare their prices for the technology and benefits they receive from that technology. Even though this factor was neglected in some studies (Zavolokina, Dolata \& Schwabe, 2016) we chose this factor to identify whether the value added in financial institutions by using Fintech is significant or whether this monetary cost motivated employees to use more in their daily lives working life. We have drawn the following hypothesis:

H6: Monetary value positively influences the behavioral intention to adopt Fintech 


\section{Self-Efficacy (SE)}

If a user can operate a task using new technology without others' assistance, we can say that the user attained self-efficacy (Compeau \& Higgins, 1995). If SE is not found at a satisfactory level or if an employee cannot conveniently use Fintech, he or she will get stuck in the workplace. By examining this factor, we tried to conclude whether the employees are familiar with this new technology and at the same time whether they get enough time to complete their assigned task for which the technology is provided to them.

H7: Self-efficacy has a significant influence on the behavioral intention to adopt Fintech

\section{Nervousness (N)}

If a user feels that a new system is intimidating or if anxiety works whenever he or she uses technology, we can say that this new technology creates nervousness in the users, which may have a negative influence on using this system (Compeau, Higgins \& Huff, 1999). We wanted to verify whether employees of financial sectors feel discomfort or hesitation using Fintech for fear of making mistakes that they may not correct.

H8: Nervousness has a negative influence on the behavioral intention to adopt Fintech

\section{Behavioral Intention (BI)}

Behavioral intention is defined as the degree to which a person perceives willingness to adopt new technology (Hossain, 2020). It acts as an indicator of the actual usage of Fintech in the near future. Empirical studies also found a strong correlation between behavioral intention and actual use behavior. We expected that

H9: Behavioral intention has a significant positive influence on Fintech usage 


\section{AgE AS A MODERATING FACTOR}

Generally, age, gender, experience, generation, culture, etc., has been used as a moderating factor in previous technology adoption researches. In developing countries, including Bangladesh, it has been found that women are reluctant to use new technologies compared to men. Additionally, the young generations are likely to use new technology, whereas technophobia works to aged groups. However, in our country perspective, we observe that both male and female employee ratios are almost equal and both are similarly holding all the position in financial institutions; we preferred age as a moderating factor to evaluate the strength between independent variables and dependent variable ignoring all other moderating factors mentioned here. Furthermore, we cross-checked whether the age and experience of the employees are positively related and found that the employees who are aged have more job experiences.

Figure 1. Positive Relationships between Age and Job Experience

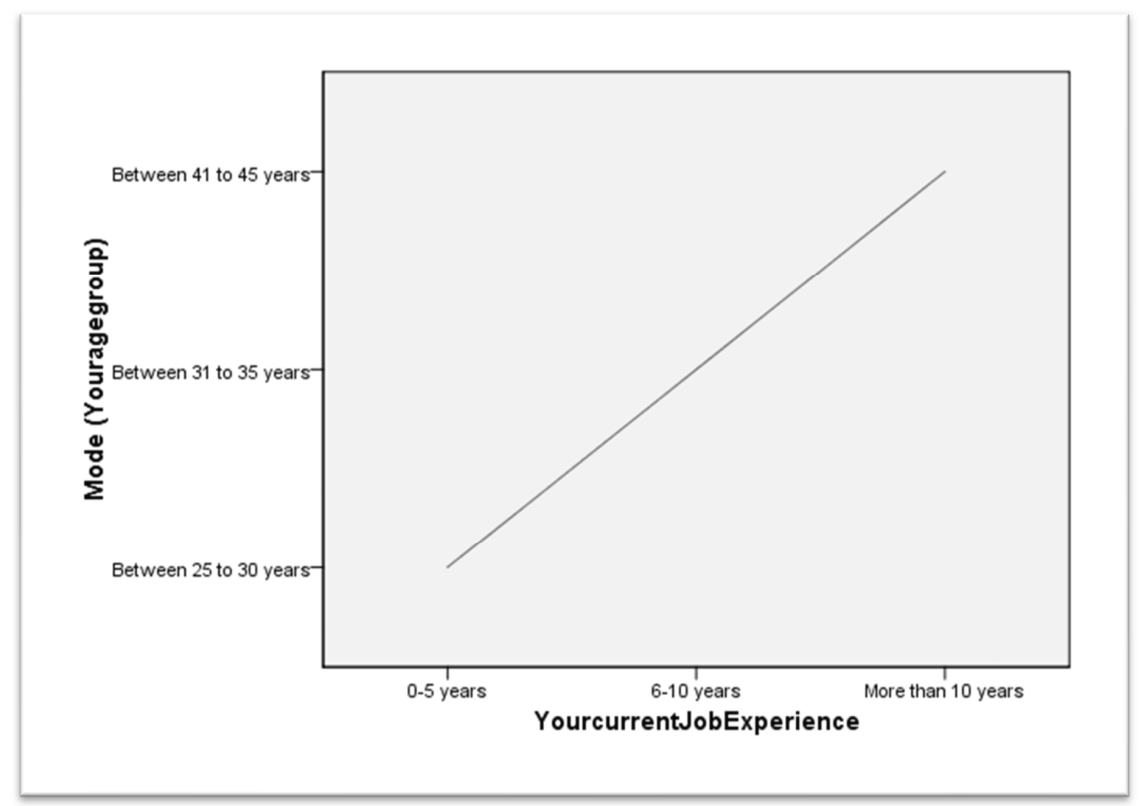


Our hypotheses are:

H10: Age has a significant moderating role in the relationship between performance expectancy and behavioral intention to adopt Fintech

H11: Age has a significant moderating role in the relationship between effort expectancy and behavioral intention to adopt Fintech

H12: Age has a significant moderating role in the relationship between social influence and behavioral intention to adopt Fintech

H13: Age has a significant moderating role in the relationship between facilitating condition and behavioral intention to adopt Fintech

H14: Age has a significant moderating role in the relationship between perceived reliability and behavioral intention to adopt Fintech

H15: Age has a significant moderating role in the relationship between added value and behavioral intention to adopt Fintech

H16: Age has a significant moderating role in the relationship between self-efficacy and behavioral intention to adopt Fintech

H17: Age has a significant moderating role in the relationship between nervousness and behavioral intention to adopt Fintech

\section{RESEARCH METHODOLOGY}

In few decades, we can see that technology enhancement is so rapid. Even though Fintech is an emerging issue, it is not new for financial sectors in our country. Since most users (more than 60\%) belong to financial institutions, we selected this sector as our target population for this study.

The items we have selected for the study were mainly adopted from previous studies (Venkatesh et al., 2003). Performance expectancy, effort expectancy, facilitating conditions, and social influences were taken from the original UTAUT model developed by Venkatesh et al. (2003). The items of perceived reliability were adopted from (Ganguli \& Roy, 2011; Gunawardana \& Perera, 2015). Additionally, Price value, behavioral intention, and the actual use behavior were taken from (Venkatesh et al., 2012).

Before collecting data, we have arranged a survey to ensure the content validity of the items. Our motto was to identify the most representative factors fitted in the context of Bangladesh, and we were concerned with users' points of view as well. Moreover, literature reviews, open discussions with academicians and researchers helped to generate the measurement items. For pretest- 
ing, we set questionnaires, randomly picked three banks, two NBFIs, two brokerage firms. We physically went to the organizations, tested questionnaires with 25 randomly selected respondents for this pilot test. The outcomes obtained from face-to-face interviews and questionnaires helped us to modify our factors. After the pre-pilot test, we set our final questionnaire to test our theoretical model and hypothesis relationship.

Since we cannot address the reliable list of total users of Fintech in our target group, we followed a convenience sampling method. We collected questionnaires from 293 respondents, out of which 265 valid responses were obtained. We also used the judgment sampling method for selecting the organizations. We selected top-ranked ten banks, five NBFIs, and five brokerage firms from the financial sectors in Bangladesh.

We reached out to the prospective employees of the selected institutions via email. For convenience, we shared a google form link to fill up the set questionnaire. We assured them of maintaining their confidentiality and privacy of the data before initiating the survey. The first section consisted of the questions on respondents' personal information. The second section dealt with their orientation/ familiarization with the Fintech, while the third section comprised a series of questions about the factor analysis. Open-ended questions on the respondents' intention to adopt Fintech and multiple questions for each value construct were presented sequentially using five-point Likert scales.

After cleaning all collected responses, we arranged and coded them in SPSS for further analysis. To test and validate the contents of our model, we applied the generalized least square method-a statistical technique based on the structural equation model (SEM). Then we have drawn the UTAUT model with the help of SPSS AMOS to verify the significance level of the variables.

\section{DATA ANALYSIS \& FINDINGS}

Employees were grouped based on their current age. The frequency table reveals that the majority of respondents were between 25 to 30 years old. 
Table 2. Frequency Table (Respondents' Age Group)

\begin{tabular}{|c|c|c|c|c|c|}
\hline \multicolumn{6}{|c|}{ Your age group } \\
\hline & & Frequency & Percent & Valid Percent & $\begin{array}{c}\text { Cumulative } \\
\text { Percent }\end{array}$ \\
\hline \multirow[t]{6}{*}{ Valid } & 1. Between 25 to 30 years & 109 & 41.1 & 41.1 & 41.1 \\
\hline & 2. Between 31 to 35 years & 68 & 25.7 & 25.7 & 66.8 \\
\hline & 3. Between 36 to 40 years & 30 & 11.3 & 11.3 & 78.1 \\
\hline & 4. Between 41 to 45 years & 38 & 14.3 & 14.3 & 92.5 \\
\hline & 5. Above 46 & 20 & 7.5 & 7.5 & 100.0 \\
\hline & Total & 265 & 100.0 & 100.0 & \\
\hline
\end{tabular}

S o u r c e : frequency table drawn by the authors using SPSS.

Almost all the users responded that they are familiar with Fintech. 99\% answered that they use Fintech for every working day, mainly mobile banking, facilitating financial advice. $7 \%$ out of total respondents mentioned that they also use Fintech for additional innovation to some extent. Whenever they were asked whether they recommend any modification in Fintech, 96\% of the respondents answered that modification is required mainly to make it more convenient. The majority responded that they believe Fintech will improve their job performance as it saves time and ensures advanced security.

$90 \%$ agreed that they feel Fintech is convenient and simple to use, and a majority of them believe that it has reduced their work pressure. 
Figure 2. Why respondents think using Fintech is Convenient and simple to use

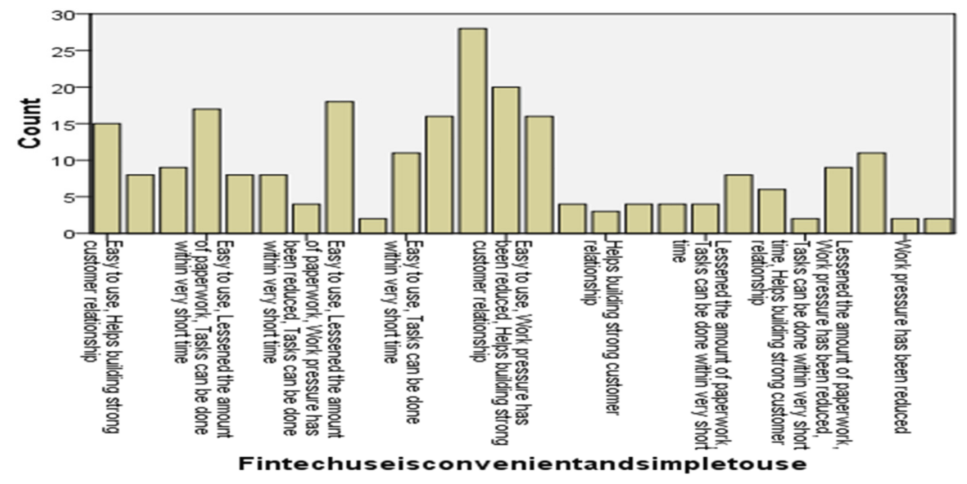

S o u r c e : graph drawn by the authors using SPSS.

Moreover, 30 out of 265 users responded that their supporting firms are not ready to facilitate, for which they mainly face difficulty to satisfy customers immediately.

Figure 3. Problems that respondents face if supporting firms are not ready to facilitate the use of Fintech

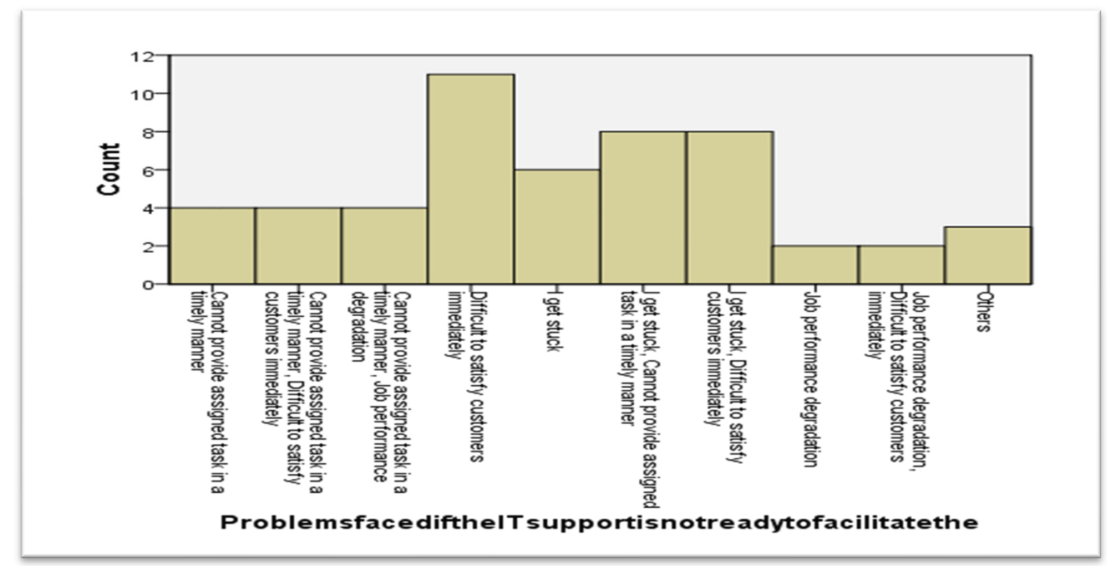

S o u r c e : graph drawn by the authors using SPSS. 
Additionally, 14\% of the total questionnaire participants believe that Fintech does not ensure trust and confidence as they faced security hazards when they used Fintech.

Figure 4. Why the respondents do not have trust and confidence when they use Fintech

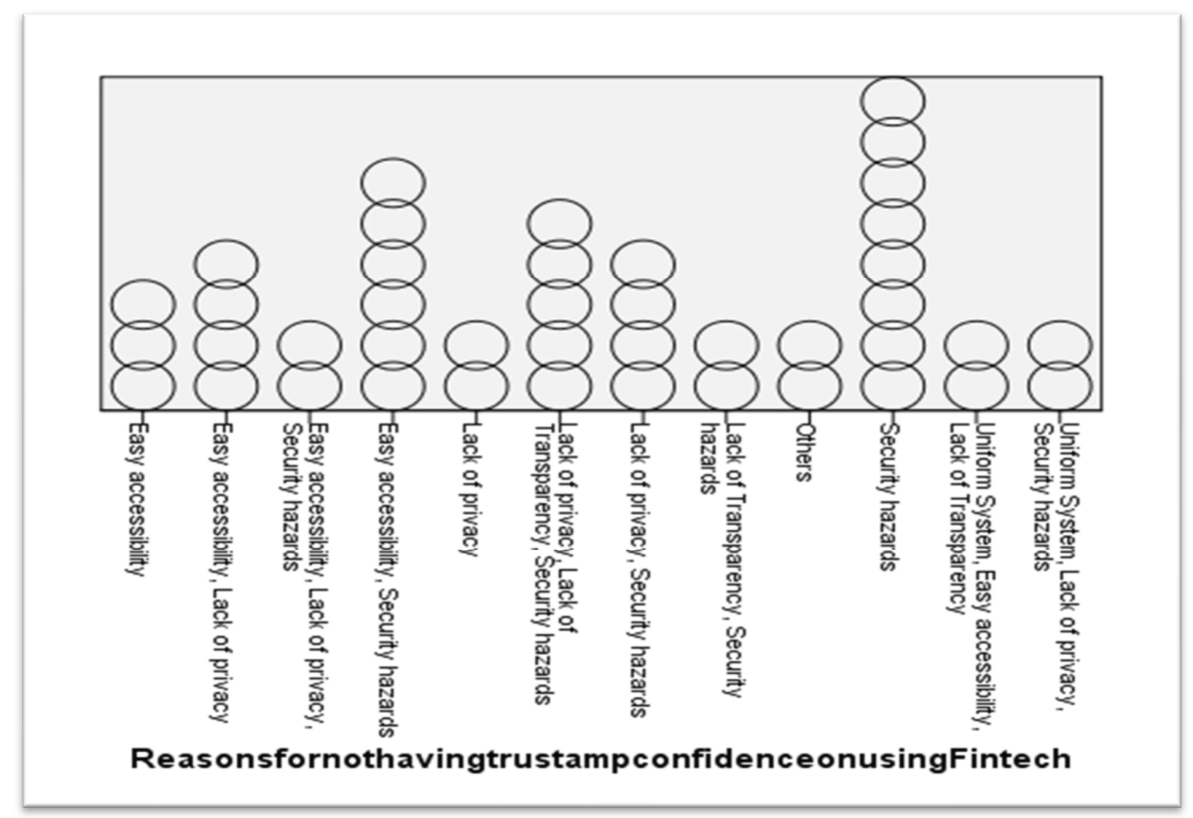

S o u r c e : graph drawn by the authors using SPSS.

Moreover,17\% of respondents think that the organization's infrastructure cost that the organization pays for Fintech does not encourage them to use Fintech as the majority believe that they are still not familiar with this new system. 
Figure 5. Why respondents believe the organization's infrastructure cost does not encourage using Fintech

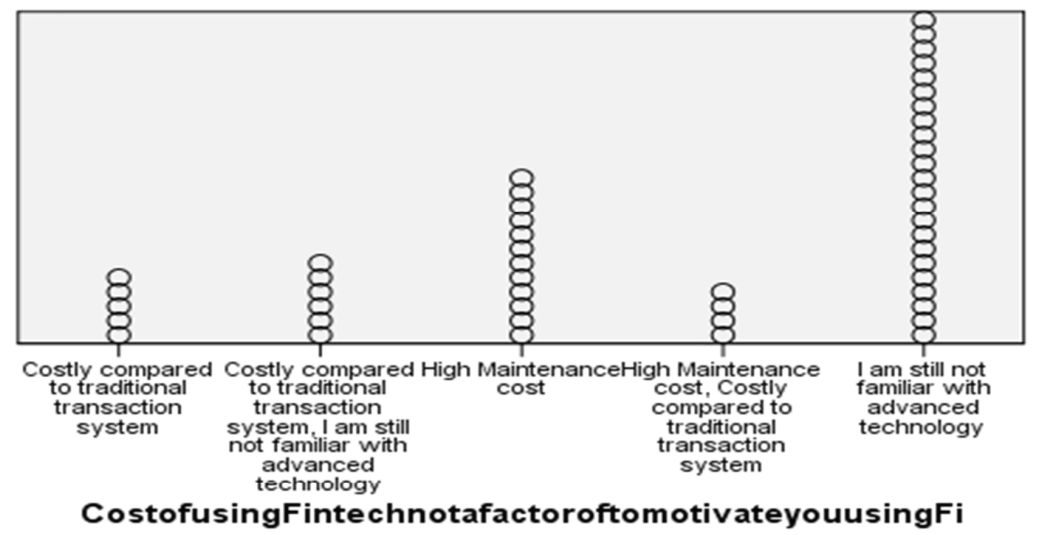

S o u r c e : graph drawn by the authors using SPSS. 
Figure 6. Research Model Applying SPSS AMOS Graph (Without Moderating Factor)

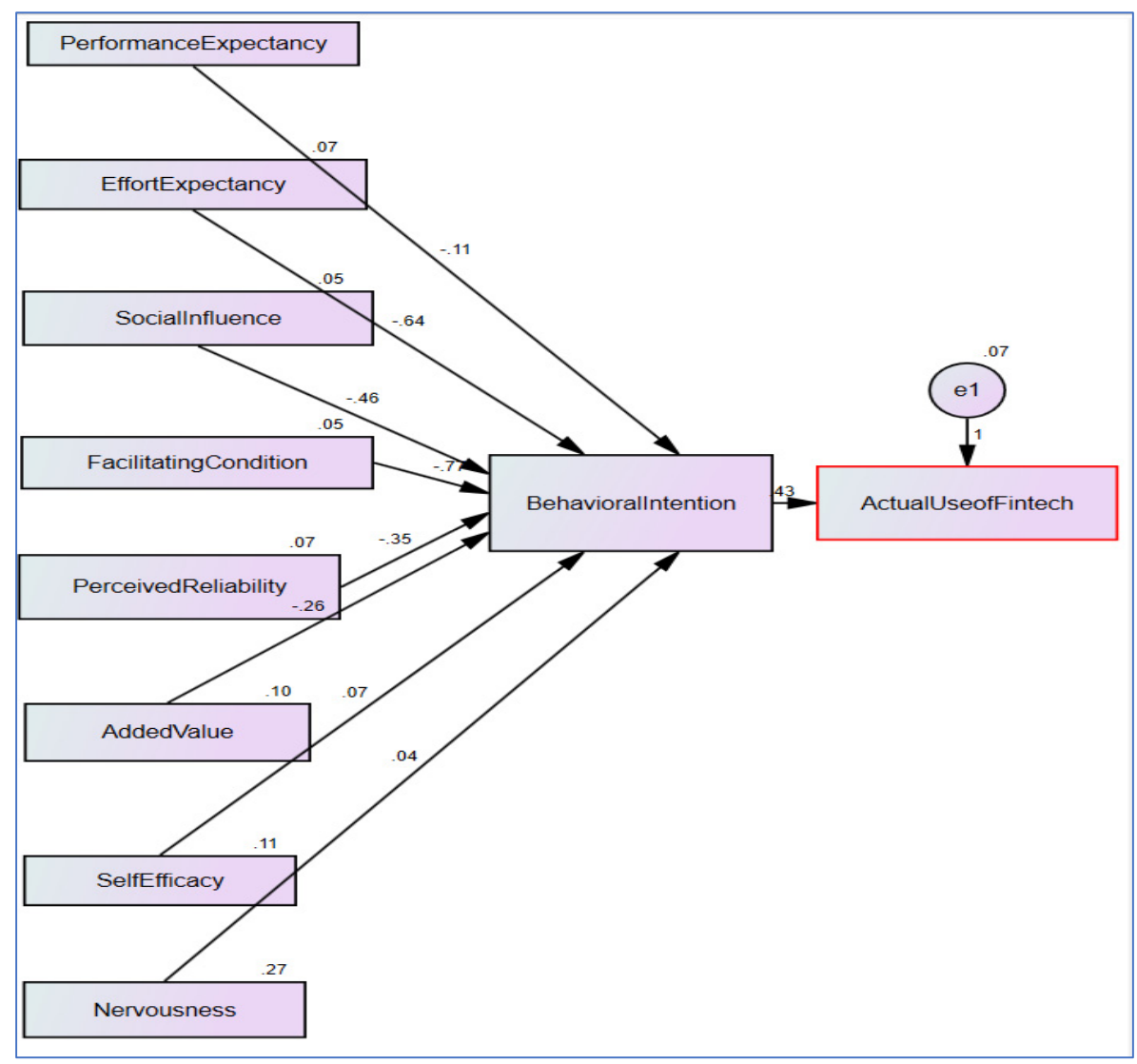

S o u r c e : UTAUT Model Created by the authors using SPSS AMOS Graph. 
Table 3. Analysis of the Influencing Factors Using Regression Model (Without Moderating Factor)

\begin{tabular}{|c|c|c|c|c|c|}
\hline \multicolumn{6}{|l|}{ Estimates (Group number 1 - Default model) } \\
\hline \multicolumn{6}{|l|}{ Scalar Estimates (Group number 1 - Default model) } \\
\hline \multicolumn{6}{|l|}{ Generalized Least Squares Estimates } \\
\hline \multicolumn{6}{|l|}{ Regression Weights: (Group number 1 - Default model) } \\
\hline & Estimate & S.E. & C.R. & $\mathrm{P}$ & Label \\
\hline Behaviorallntention <--- PerformanceExpectancy & -.105 & .085 & -1.231 & .218 & \\
\hline BehavioralIntention <--- EffortExpectancy & -.638 & .159 & -4.003 & $* * *$ & \\
\hline Behaviorallntention <--- Sociallnfluence & -.464 & .134 & -3.463 & $* * *$ & \\
\hline BehavioralIntention <--- FacilitatingCondition & -.770 & .140 & -5.482 & $* * *$ & \\
\hline Behaviorallntention <--- PerceivedReliability & -.353 & .122 & -2.887 & .004 & \\
\hline Behaviorallntention <--- AddedValue & -.260 & .083 & -3.120 & .002 & \\
\hline Behaviorallntention <--- SelfEfficacy & .071 & .097 & .728 & .467 & \\
\hline Behaviorallntention <--- Nervousness & .043 & .059 & .723 & .470 & \\
\hline ActualUseofFintech <--- Behaviorallntention & .432 & .069 & 6.271 & $* * *$ & \\
\hline
\end{tabular}

Note: ${ }^{*} \mathrm{P}<.05,{ }^{* *} \mathrm{P}<.01,{ }^{* * *} \mathrm{P}<.001$.

S o u r c e : Regression Model analyzed by the Authors using SPSS AMOS.

After analyzing the data with the help of SPSS AMOS graph (Figure 6), we have found the result of the structural equation model where the Generalized least square method has been used. In this stage, we can conclude the tested hypothesis result. At 5\% significance level, we can say that perceived reliability and price value positively influence the behavioral intention to adopt Fintech. At $0.1 \%$ significance level, effort expectancy, social influence, and facilitating condition positively influence the behavioral intention to adopt Fintech. Finally, we have observed that behavioral intention significantly influenced the actual usage behavior of Fintech. 
Figure 7. Research Model Applying SPSS AMOS Graph (With Moderating Factor)

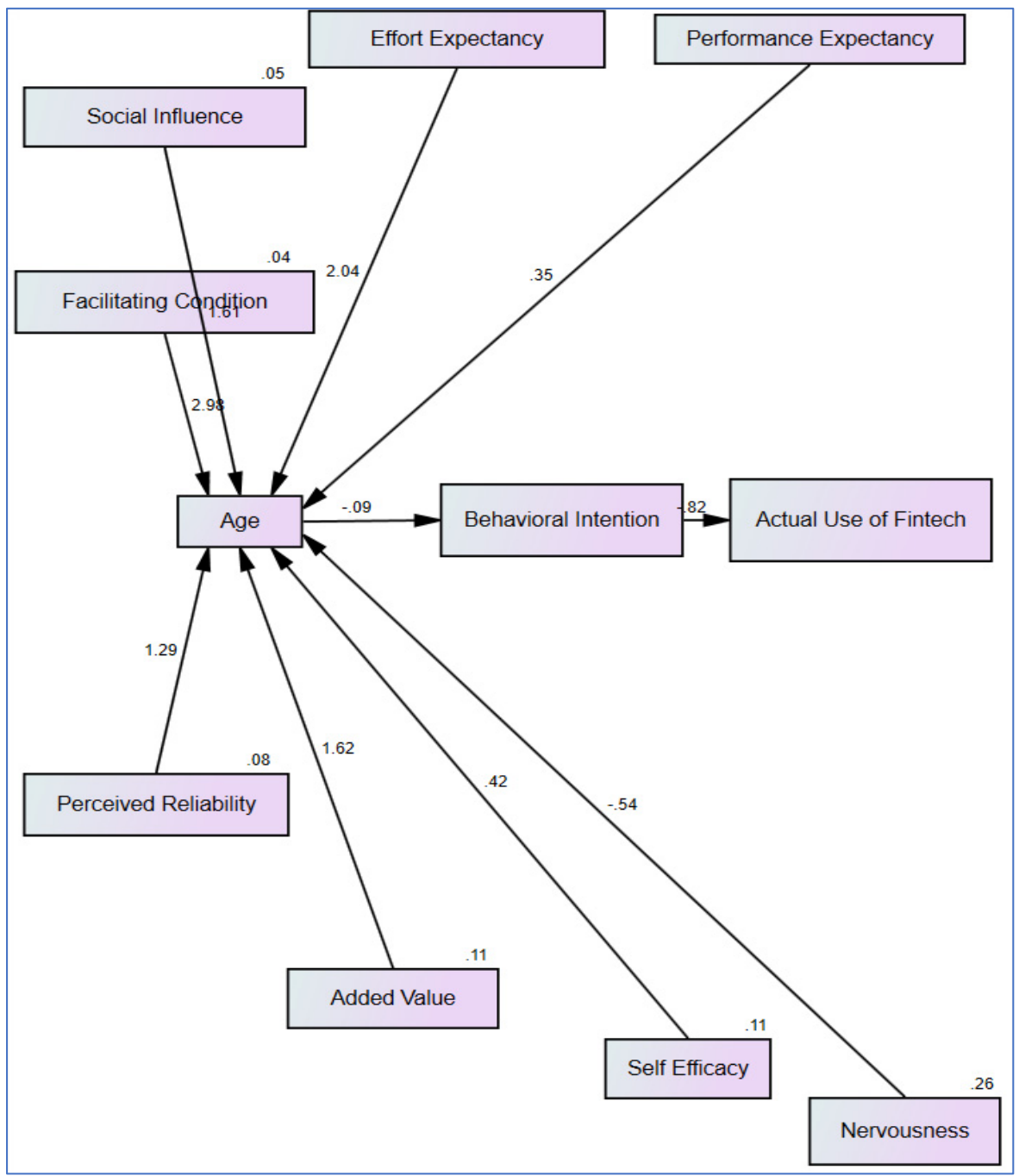

S o u r c e : UTAUT Model Created by the authors using SPSS AMOS Graph. 
Table 4. Analysis of the Influencing Factors Using Regression Model (With Moderating Factor)

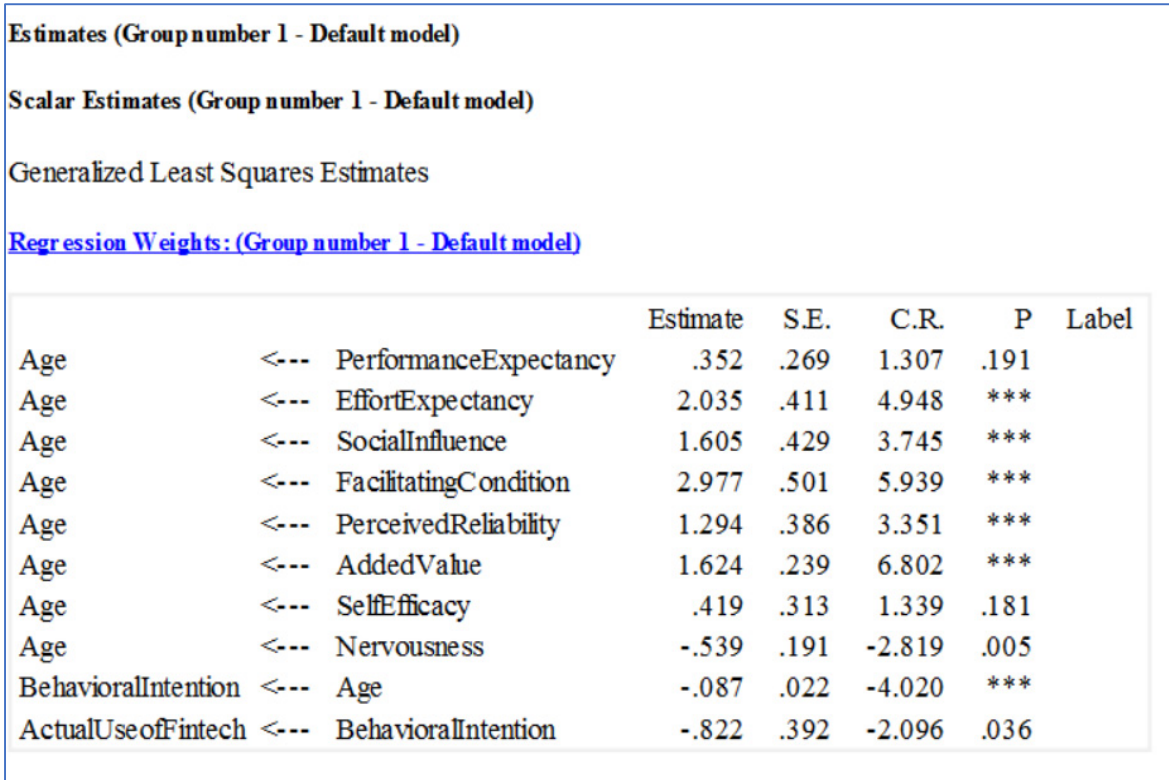

N o t e : ${ }^{*} \mathrm{P}<.05,{ }^{* *} \mathrm{P}<.01,{ }^{* * *} \mathrm{P}<.001$

S o u r c e : Regression Model analyzed by the authors using SPSS AMOS.

To see the impact of moderating effect of age, we have run the UTAUT model with SPSS AMOS again (Figure 7 ) and found that at $0.1 \%$ significance level, age has a significant moderating role in the relationship between performance expectancy, effort expectancy, social influence, facilitating condition, perceived reliability and behavioral intention to adopt Fintech. Additionally, nervousness negatively influences the behavioral intention of Fintech users. Moreover, behavioral intention of fintech users positively influences the actual use with the existence of moderating variable.

For further verification, we have tested the correlation between the independent variables and age. As our measurement is based on the Likert scale, we have followed Spearman's correlation test. In SPSS, with bivariate correlation analysis, we obtained our outputs significant, as the correlated values are less than .05. For example, we can see the table below where the correlation between age and nervousness is $0.044(<.05)$. Furthermore, the correlation coeffi- 
cient between age and nervousness is negative, which directs that nervousness works more for the young aged than the aged users.

Table 5. Correlation between age and nervousness

\begin{tabular}{|c|c|c|c|c|}
\hline \multicolumn{5}{|c|}{ Correlations } \\
\hline & & & Age & Nervousness \\
\hline \multirow[t]{6}{*}{ Spearman's rho } & \multirow[t]{3}{*}{ Age } & Correlation Coefficient & 1.000 & $-.124^{*}$ \\
\hline & & Sig. (2-tailed) & . & .044 \\
\hline & & $N$ & 265 & 265 \\
\hline & \multirow[t]{3}{*}{ Nervousness } & Correlation Coefficient & $-.124^{*}$ & 1.000 \\
\hline & & Sig. (2-tailed) & .044 & . \\
\hline & & $N$ & 265 & 265 \\
\hline
\end{tabular}

*. Correlation is significant at the 0.05 level (2-tailed).

S o u r c e : output of the correlation run by authors using SPSS.

\section{ConCLusion}

We conducted the survey to examine the factors influencing the adoption of Fintech in the financial institutions (Banks, NBFI, Brokerage firms). After applying the suited model, we have found the impact of the selected factors on the usage of Fintech. The study concludes that users feel convenient and wish to be connected with Fintech if it is easily understandable to them. The people, for instance, co-workers, supervisors, subordinates, or employees of the same industry firms, play a significant role in influencing the behavioral intention to adopt Fintech. Additionally, the result proved that during the time they face difficulty using Fintech, if employees get assistance from the facilitator firms who mainly provide IT support, it will significantly influence behavior.

Furthermore, respondents believe that they will perform a job reliably and accurately with the help of new technology. Moreover, the study concluded that their organization's infrastructure cost for using Fintech encourages the employees to use Fintech. Nervousness, on the other hand, negatively influences the behavioral intention of Fintech users. The study revealed another insightful finding; nervousness works more for the young than the aged users. Finally, 
we have observed that behavioral intention significantly influences the actual usage behavior of Fintech.

We hope that in addition to the theoretical contribution, these findings will help the policymakers, regulators, and government develop practical guidelines for the successful implication of Fintech use in our country. The factors that we have found significant should be given priority for increasing the usage of Fintech. Furthermore, the factors that we have discovered insignificant should also be considered to be the influencing factors for Fintech adoption in the near future. As we have found that young users face anxiety, they should be given proper training to use this system more efficiently. Therefore, it is essential to focus mainly on the actual usage of Fintech on a regular basis. Only then can we prove ourselves to be more techno-updated and compete with the digital world. Both public and private sectors should work together to make it possible.

In fine, we expect that the findings of the study might help the financial industries of Bangladesh to observe the subsequent impact on the adoption of Fintech. Furthermore, the result might also benefit other sectors of Bangladesh to learn a lesson and apply Fintech practically. Quantitative analysis can be done if the actual usage of Fintech by the users is adequately recorded. We are optimistic that the study can be a milestone in examining the factors affecting Fintech adoption in other developing countries like Bangladesh. Therefore, there exists a large field of future research.

\section{Limitations}

Even though we have completed our study successfully, but we had some limitations. The original UTAUT model was on a longitudinal study, but we measured the respondents' intentions and usage of Fintech for a single point of time. In the future, we should conduct longitudinal studies on Fintech adoption so that we can compare the findings with previous studies. 


\section{REFERENCES}

Brandl, B., \& Hornuf, L. (2017). Where Did Fintechs Come from, and Where Do They Go? The Transformation of the Financial Industry in Germany after Digitalization. SSRN Papers, 25. https://papers.ssrn.com/sol3/papers.cfm?abstract_id=3036555.

BTRC (2020). Bangladesh Telephone Regulatory Commission. Bangladesh: Ministry of Telecommunication, Dhaka.

Chakraborti, A. (2019). The promise of FinTech for Bangladesh. Dhaka, Bangladesh: The Daily Star, https://www.thedailystar.net/business/the-promise-fintech-bangladesh-1602703.

Chen, L. (2016). From Fintech to Finlife: the case of Fintech Development in China. China Economic Journal, 9(3), 225-239. http://dx.doi.org/10.1080/17538963.2016.121 5057.

Compeau, D., Higgins, C.A., \& Huff, S. (1999). Social cognitive theory and individual reactions to computing technology: a lonnitudedinal study. MIS Quartely, 23(2), 145158. http://dx.doi.org/10.2307/249749.

Compeau, D.R., \& Higgins, C.A. (1995). Computer self-efficacy: development of a measure and initial test. MIS Quarterly, 19(2), 189-211. http://dx.doi.org/10.2307/249688.

Ganguli, S. , \& Roy, S.K. (2011). Generic Technology-Based Service Quality Dimensions in Banking: Impact on Customer Satisfaction and Loyalty. International Journal of Bank Marketing, 29, 168-189.

Guild, J. (2017). Fintech and the Future of Finance. Asian Journal of Public Affairs, 17-20.

Gunawardhana, N., \& Perera, C. (2015). Classification of Failure Factors in Information Systems. International Journal for Innovation Education and Research, 3(3), 201-211. https://dx.doi.org/10.31686/ijier.vol3.iss3.339.

Hornuf, C.H. (2018). The emergence of the global fintech market: economic. Small Business Economics, 53, 81-105. http://dx.doi.org/10.2139/ssrn.2830124.

Hossain, R. (2020). The Financial Express, https://thefinancialexpress.com.bd/views/ fintech-in-the-context-of-bangladesh-1587308873.

Koffi, H.W. (2016). The Fintech Revolution: An Opportunity for the West African Financial Sector. Open Journal of Applied Sciences, 6(11), 771-782. http://dx.doi. org/10.4236/ojapps.2016.611068.

Lee, E-J., Lee, J., \& Eastwood, D. (2003). A Two-Step Estimation of Consumer Adoption of Technology-Based Service Innovations. The Journal of Consumer Affairs, 2(37), 256282. http://dx.doi.org/10.1111/j.1745-6606.2003.tb00453.x.

Lee, T., \& Kim, H.-W. (2015). An Exploratory Study on Fintech Industry in Korea: Crowdfunding Case. 2nd International conference on Innovative Engineering Technologies, 58-64. http://dx.doi.org/10.15242/IIE.E0815045.

Micu, I., \& Micu, A. (2016). Financial Technology (FinTech) and its Implementation on the Romanian Non-Banking Capital Market. SEA - Practical Application of Science, 11, 79-384.

Puschmann, T. (2017). Fintech. Business \& Information Systems Engineering, 59, 69-76. http://dx.doi.org/10.1007/s12599-017-0464-6. 
Sadrul Huda, S.S.M., Kabir, M.H., Popy, N.N., \& Saha, S. (2020). Innovation in financial services: the case of Bangladesh. Copernican Journal of Finance \& Accounting, 9(1), 31-56. http://dx.doi.org/10.12775/CJFA.2020.002.

Skan, J.D. (2015). The Future of Fintech and Banking: Digitally disrupted or reimagined? https://technation.io/news/future-of-fintech.

Steele, R., Lo, A., Secombe, Ch., \& Wong, Y. (2009). Elderly persons' perception and acceptance of using wireless sensor networks to assist healthcare. International journal of medical informatics, 78, 788-801. http://dx.doi.org/10.1016/j.ijmedinf.2009.08.001.

Vasiljeva, T. (2016). Commercial banks and FINTECH companies in the digital transformation: challenges for the future. Journal of Business Management, 11, 25-33.

Venkatesh, V., Morris, M.G., Davis, G.B., \& Davis, F.D. (2003). User Acceptance of Information Technology: Toward a Unified View. MIS Quarterly, 27(3), 425-478. http:// dx.doi.org/10.2307/30036540.

Venkatesh, V., Thong, J.Y.L., \& Xu, X. (2012). Consumer Acceptance and Use of Information Technology: Extending the Unified Theory of Acceptance and Use of Technology. MIS Quarterly, 36(1), 157-178. http://dx.doi.org/10.2307/41410412.

Wonglimpiyarat, J. (2017). FinTech banking industry: a systemic approach. Foresight, 19(6), 590-603. http://dx.doi.org/10.1108/FS-07-2017-0026.

Wulan, V.R. (2017). Financial technology (fintech) a new transaction in future. Journal of Electrical Engineering and Computer Sciences, 2(1), 177-182.

Yongwoon S., \& Dong-Hee, S. (2016). Analyzing China's Fintech Industry from the Perspective of Actor-Network Theory. Telecommunications Policy, 40(2-3), 168-181.

Zavolokina, L., Dolata, M., \& Schwabe, G. (2016). FinTech transformation: how it-enabled innovations shape the financial sector. In S., Feuerriegel, D. Neumann (Eds). EnterpriseApplications, Markets and Services in the Finance Industry. Cham: Springer. http://dx.doi.org/10.1007/978-3-319-52764-2_6. 


\section{APPENDIX}

\section{List of Measures}

Likert scale $[(1)=$ Strongly disagree $;(2)=$ Disagree; $(3)$ = Neutral; (4) = Agree; (5) $=$ Strongly agree $]$

\begin{tabular}{|c|c|c|c|c|c|c|}
\hline \multicolumn{2}{|c|}{ Performance Expectancy (PE) } & 1 & 2 & 3 & 4 & 5 \\
\hline PE1 & Fintech is useful in my job & & & & & \\
\hline PE2 & Fintech usage provides better scope of meeting my needs & & & & & \\
\hline PE3 & Fintech helps me to accomplish my tasks more quickly & & & & & \\
\hline PE4 & Using Fintech increases my productivity & & & & & \\
\hline PE5 & Fintech use will enable me to get a raise & & & & & \\
\hline \multicolumn{2}{|c|}{ Effort Expectancy (EE) } & & & & & \\
\hline EE1 & Learning to operate Fintech is easy for me & & & & & \\
\hline EE2 & The way of using Fintech is clear and understandable for me & & & & & \\
\hline EE3 & I have found the Fintech is easy to use & & & & & \\
\hline EE4 & It is easy for me to become skillful at using Fintech & & & & & \\
\hline \multicolumn{2}{|c|}{ Social Influence (SI) } & & & & & \\
\hline SI1 & $\begin{array}{l}\text { Communicating with my friends/colleagues helps me to learn more } \\
\text { about Fintech. }\end{array}$ & & & & & \\
\hline $\mathrm{S} 12$ & I use Fintech because other related organizations are using Fintech. & & & & & \\
\hline $\mathrm{SI} 3$ & $\begin{array}{l}\text { People who influence my job performance think that I should use Fin- } \\
\text { tech. }\end{array}$ & & & & & \\
\hline $\mathrm{SI} 14$ & My organization has supported to use Fintech & & & & & \\
\hline SI5 & $\begin{array}{l}\text { Organizations who use Fintech are in more prestigious status than those } \\
\text { who are not familiar with Fintech }\end{array}$ & & & & & \\
\hline \multicolumn{2}{|c|}{ Facilitating Conditions (FC) } & & & & & \\
\hline FC1 & I have full IT support to use Fintech & & & & & \\
\hline FC2 & I have proper experience to use Fintech & & & & & \\
\hline FC3 & Fintech is not compatible with other systems I regularly use & & & & & \\
\hline FC4 & $\begin{array}{l}\text { IT service is available for assistance whenever I face difficulties using } \\
\text { Fintech }\end{array}$ & & & & & \\
\hline
\end{tabular}


11. Factors afFecting the adoption OF FINTECH...

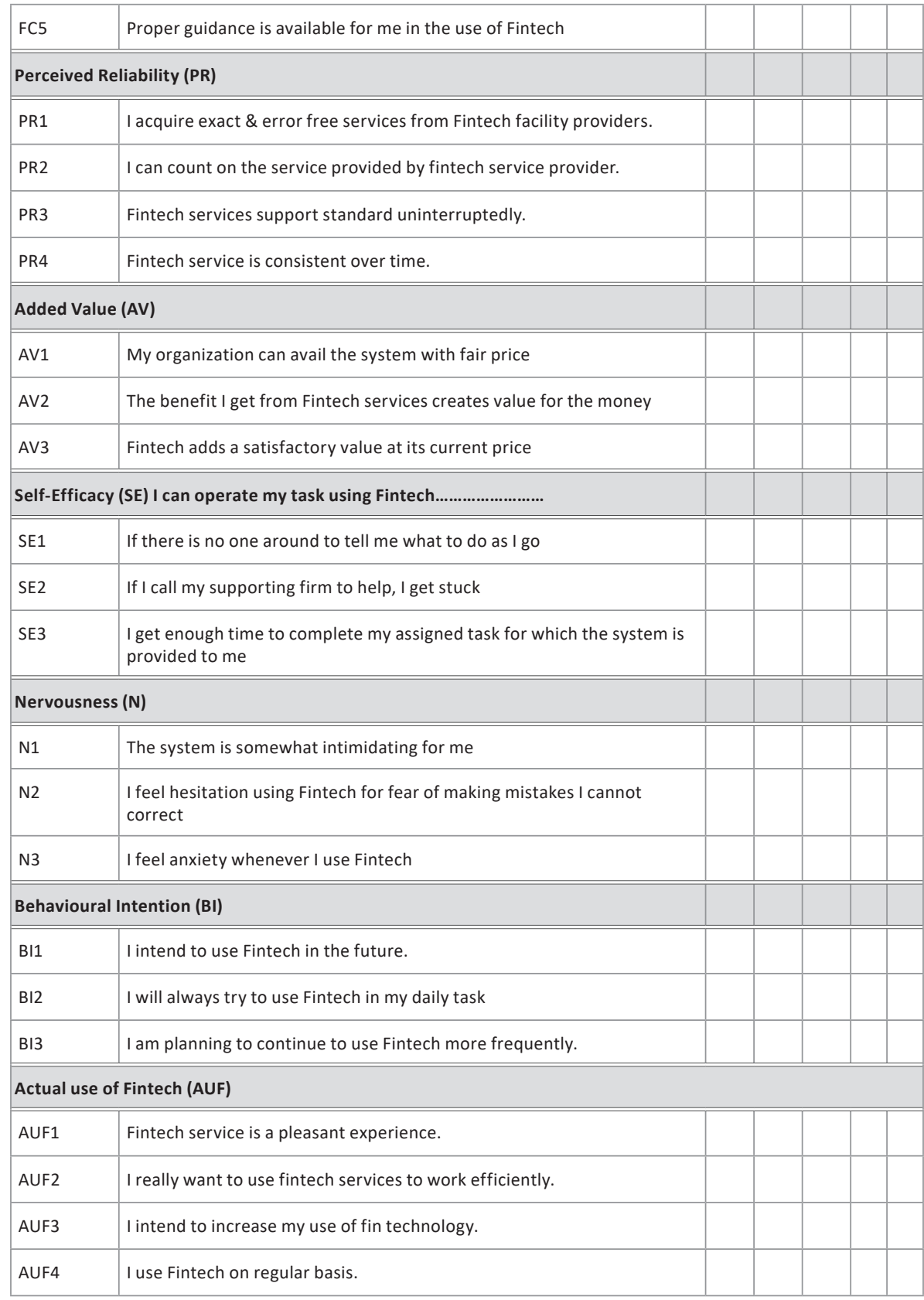

